\title{
Effect of Helicobacter Pylori Infection on Serum Vitamin D Levels Patients with Dyspepsia
}

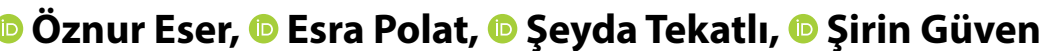

Department of Pediatrics, University of Health Sciences Turkey, Sancaktepe Şehit Prof.Dr. İlhan Varank Training and Research Hospital, Istanbul, Turkey

\begin{abstract}
Introduction: We aimed to compare serum levels of Vitamin D3 in patients with and without Helicobacter pylori (HP) infection detected with the upper gastrointestinal endoscopic examination. We hypothesized that patients diagnosed with HP pathologically had low serum vitamin D3 levels.

Methods: The study was held between July 1, 2019, and March 31, 2021, tertiary referee hospital. The upper gastrointestinal system endoscopic data of pediatric patients with treatment-resistant dyspeptic complaints who were followed up in the Pediatric Gastroenterology outpatient clinic of hospital between July 1, 2019, and March 31, 2021, were retrospectively evaluated. The age, height, height standard deviation score (SDS), weight, weight SDS, body mass index (BMI), BMI SDS, and serum Vitamin D3 levels of the patients who were divided into two groups according to the presence of HP histopathologically in the endoscopic biopsy samples were examined.

Results: Eighty-six patients were evaluated, while 58 (67.44\%) were girls and 28 (32.55\%) were boys. The median age was 14.43 (Interquartile range $[\mathrm{IQR}]=4.99$ ) years. Histopathological evaluation of biopsy materials taken from the antrum and corpus of 43 patients who underwent upper gastrointestinal endoscopy revealed HP positivity in 43 patients (50.00\%). HP was not detected in 43 patients (50.00\%). The median Vitamin D3 level was $10.00 \mathrm{ng} / \mathrm{ml}$ in the HP positive group (IQR=6.00), and the median was $14.00 \mathrm{ng} / \mathrm{ml}(\mathrm{IQR}=9.30)$ in the negative group. This study found a significant difference between HP positive and HP negative patient groups in Vitamin D3 serum levels $(p=0.033)$.

Discussion and Conclusion: Vitamin D3 serum levels were found to be significantly lower in the HP positive group than that of controls $(p=0.033)$. This finding supports that mucosal damage may affect Vitamin D3 absorption. Early diagnosis and treatment maintain their importance to prevent long-term consequences of chronic infection.
\end{abstract}

Keywords: Helicobacter pylori; pediatric; vitamin D3.

$H$ elicobacter pylori (HP) is a Gram-negative bacillus that colonizes the gastric mucosa and may cause chronic inflammatory disease. HP, whose primary host is human, may be transmitted from person to person through fecaloral or oral-oral ${ }^{[1,2]}$. The first encounter with HP infection and the gastrointestinal system invasion of the disease usually occurs in childhood ${ }^{[3]}$.

25-hydroxyvitamin D3 (25-OH-D3) is an active vitamin hormone in various metabolic pathways, especially calcium and bone metabolism. 25-OH-D3 precursors can be taken orally with food and synthesized by sunlight in human skin. 25-OH-D3, a fat-soluble vitamin, is absorbed in the duodenum like other fat-soluble vitamins. It has been shown that 25-OH-D3 absorption is also affected by infections that disrupt the stomach and duodenal mucosa ${ }^{[4,5]}$.

HP infection shows different course individually, and it is known that it may be the precursor of many diseases on the gastric mucosa, from gastritis to adenocarcinoma. HP

Correspondence (İletişim): Oznur Eser, M.D. Saglik Bilimleri Universitesi, Sancaktepe Sehit Prof. Dr. İlhan Varank Egitim ve Arastirma Hastanesi, Cocuk Sagligi ve Hastaliklari Anabilim Dali, Istanbul, Turkey

Phone (Telefon): +90 5316550970 E-mail (E-posta): oznur0642@gmail.com

Submitted Date (Başvuru Tarihi): 01.05.2021 Accepted Date (Kabul Tarihi): 17.05.2021

Copyright 2021 Haydarpaşa Numune Medical Journal

OPEN ACCESS This is an open access article under the CC BY-NC license (http://creativecommons.org/licenses/by-nc/4.0/) 
is one of the most important causes of micronutrient deficiency in adult patients with various mechanisms ${ }^{[6,7]}$. Although HP is known to be acquired in childhood and inflammation begins at this period of life, studies of HP associated in the pediatric age group are limited.

In this study, patients with treatment-resistant dyspeptic complaints followed in our tertiary outpatient pediatric gastroenterology department were evaluated. We aimed to compare serum levels of 25-OH-D3 in patients with and without HP infection detected with the upper gastrointestinal endoscopic examination. We hypothesized that patients diagnosed with HP pathologically had low serum 25-OH-D3 levels.

\section{Materials and Methods}

The upper gastrointestinal system endoscopic data of pediatric patients with treatment-resistant dyspeptic complaints who were followed up in the Pediatric Gastroenterology outpatient clinic of BLINDED* Hospital between July 1, 2019, and March 31, 2021, were retrospectively evaluated. Ethics committee approval was taken from the local ethics committee (Decision number: 2021-136).

Patients with treatment-resistant dyspeptic complaints who underwent upper gastrointestinal system endoscopy were included in the study. It was determined by histopathological examination of biopsy samples taken during upper gastrointestinal system endoscopy, which is the reference method for diagnosing HP infection, as recommended in the guide published by ESPGHAN in $2016^{[7]}$. The other records (i.e., serum 25-OH-D3 levels) of the patients were retrospectively reviewed and recorded from the hospital information system. Patients between the ages of 4 and 18 were included in the study, and the patients were divided into two groups as HP infection positive and negative. Patients with chronic and systemic diseases were excluded from the study. Age, height, height standard deviation score (SDS), (also known as Z-score), weight, weight SDS, body mass index (BMI), BMI SDS, and serum 25-OH-D3 levels of all included patients were recorded for statistical analysis. Similar to the previous literature, the normal serum value for $25-\mathrm{OH}-\mathrm{D} 3$ was considered $20 \mathrm{ng} / \mathrm{ml}$; and below this serum level was regarded as $25-\mathrm{OH}-\mathrm{D} 3$ deficiency ${ }^{[8]}$.

\section{Statistical Analysis}

Gaussian distributed data were presented with mean and standard deviation (SD), and those that did not show a normal distribution were presented with median and interquartile range (IQR). Student t-test was used for para- metric analysis, and Mann-Whitney U-test was used for non-parametric analysis of study groups. The statistical significance level was set as $p<0.05$.

\section{Results}

Eighty-six patients were evaluated, while 58 (67.44\%) were girls and 28 (32.55\%) were boys. The youngest patient included in the study was 4 years and 3 months old, while the oldest patient was 17 years and 9 months old; the median age was $14.43(\mathrm{IQR}=4.99)$ years. Histopathological evaluation of biopsy materials taken from the antrum and corpus of 43 patients who underwent upper gastrointestinal endoscopy revealed HP positivity in 43 patients (50.00\%). HP was not detected in 43 patients (50.00\%). All of the continuous parameters examined were not normally distributed except for BMI (Table 1). BMI means are 18.81 \pm 3.86 for the HP positive group and $17.82 \pm 3.18$ for the HP negative group (Student t-test $\mathrm{p}=0.195$ ). The median 25-OH-D3 level was $10.00 \mathrm{ng} / \mathrm{ml}$ in the $\mathrm{Hp}$ positive group ( $\mathrm{IQR}=6.00)$, and the median was $14.00 \mathrm{ng} / \mathrm{ml}(\mathrm{IQR}=9.30)$ in the negative group. This study found a significant difference between $\mathrm{HP}$ positive and HP negative patient groups in 25-OH-D3 serum levels $(p=0.033)$.

\section{Discussion}

HP is a Gram-negative spiral-shaped bacillus. It is one of the main factors that affect the gastrointestinal system and cause micronutrient deficiency by triggering chronic infection in humans $[9,10]$. HP contamination occurs through the fecal-oral route in early childhood, and infection especially affects socioeconomically underdeveloped societies. Almost $80 \%$ of the population in underdeveloped countries worldwide is thought to be infected with $\mathrm{Hp}[2,11,12]$. After HP colonizes in the gastrointestinal tract, it disrupts acidity with the urease enzyme, which both prepares the ground for gastroenteritis and causes malnutrition by disrupting nutrient absorption[13]. While research over the years has shown that HP is not only the precursor of dyspepsia and gastritis but also peptic ulcer and gastric cancer, $\mathrm{HP}$ has been identified among Class 1 carcinogens since 1994[10,14]. ESPGHAN/NASPGHAN pediatric HO diagnosis and treatment guideline recommend identifying symptomatic HP infection in children with biopsy samples taken by the upper gastro endoscopy method. Pediatricians should make HP eradication with appropriate medical treatment using antibiotics and proton pump inhibitors[7].

Like other infections that cause mucosal inflammation, HP may reduce the absorption of micronutrients and vita- 
Table 1. Clinical distribution and evaluation of the case and control groups

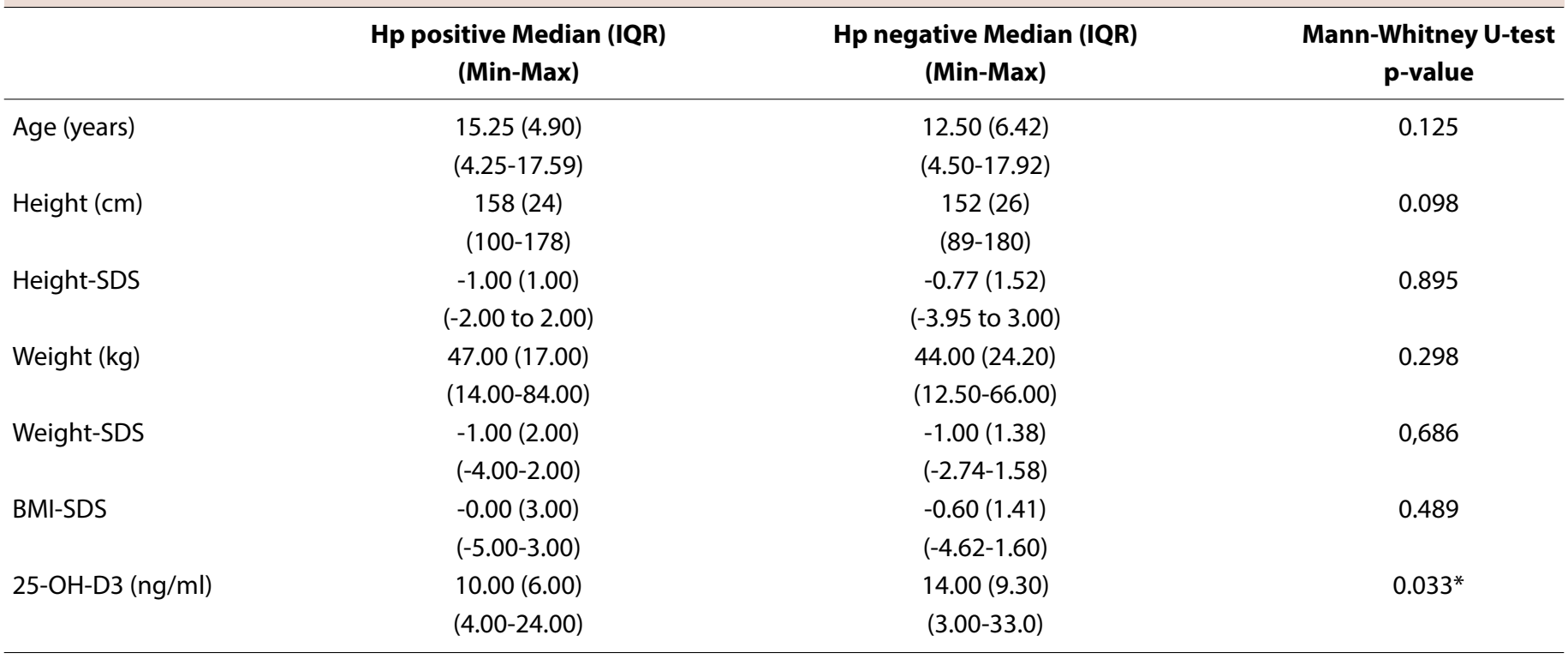

IQR: Interquartile range; SDS: Standard deviation score; BMI: Body mass index; $\left(^{*}\right)$ : Indicates significant difference; $\mathrm{OH}$ : Hydroxyvitamin; 25-OH-D3: 25-hydroxyvitamin D3.

mins and even cause malabsorption. Most of the studies that clearly define this relationship have been conducted in the adult age group[6,15]. Limited studies have been conducted on the growth and changes in micronutrient contents of HP infection in childhood[16-19]. Our research found that the HP positive group had higher median height SDS and median weight SDS than that of controls (Table 1). The data are very variable in studies examining the relationship between HP infection and developmental delay in children. Janjetic et al. could not find an association between $\mathrm{hp}$ infection and growth retardation, while Gao et al. and Süoglu et al.[17,19,20] found a significant level of growth retardation in patients with HP infection. Although HP infection was observed to be accompanied by short stature, its mechanism has not been clearly defined. It is known that low socio-economic level increases the frequency of HP infection. Furthermore, it is known that short stature is more common in societies with low socio-economic status due to malnutrition. The presence of HP infection causes growth retardation by disrupting nutrient absorption or worsening the existing poor nutritional status. However, as height growth is affected by many ethnic and individual factors, the presence of HP may not result in growth retardation in patients, as we have seen in our study[21].

$25-\mathrm{OH}-\mathrm{D} 3$ is a hormone that affects many different pathways in the body, especially bone metabolism. 25-OH-D3 deficiency may disrupt calcium-phosphorus metabolism and cause bone development disorders to rickets[22]. The study from Gao et al.[19] was conducted to show the relationship between childhood $\mathrm{Hp}$ infection 25-OH-D3, 6.896 infants (2.113 HP positive and $4.873 \mathrm{HP}$ negative) were retrospectively evaluated in terms of serum HP antigen and nutrient serum values, especially 25-OH-D3. As a result, 25-OH-D3 was significantly lower in the HP positive group than that of controls. Our study showed some differences from the previous study. The age group included was in the range of $4-18$, and the diagnosis was made with biopsy samples, which is the reference method for the diagnosis of $\mathrm{HP}$ [7]. Serum 25-OH-D3 level was significantly lower in the HP positive group than in the HP negative group ( $p=0.033$ ). Unfortunately, 25-OH-D3 deficiency is frequent in Turkish society. In studies conducted in our country, the mean $25-\mathrm{OH}-\mathrm{D} 3$ serum level was found below $20 \mathrm{ng} / \mathrm{dl}$ in pediatric patients[23,24]. The median serum $25-\mathrm{OH}-\mathrm{D} 3$ value in both groups included in the study was below $20 \mathrm{ng} / \mathrm{ml}$, the lower bound for 25-OH-D3 deficiency, which is the lower limit for Vitamin D deficiency. Our patients' low Vitamin D level may be related to our patient group consists of patients with drug-resistant chronic dyspepsia.

Our study has several limitations. It has a small sample size and is designed retrospectively. There is a need for prospective studies involving large groups to document micronutrient absorption disorders associated with HP infection in more detail. 


\section{Conclusion}

HP is one of the most common chronic infections around the globe. It is observed more frequently in developing countries such as our country than in developed countries. Early diagnosis and treatment maintain their importance to prevent long-term consequences of chronic infection.

Ethics Committee Approval: Study was approved by the University of Health Sciences Sancaktepe Şehit Prof. Dr. IIlhan Varank Training and Research Hospital Scientific Research Ethics Committee (date: 07/04/2021, number: 2021-136).

Peer-review: Externally peer-reviewed.

Authorship Contributions: Concept: E.P.; Design: E.P., Ö.E.; Supervision: Ş.G.; Funding; None; Materials: E.P., Ş.T.; Data Collection or Processing: Ş.T., Ö.E.; Analysis or Interpretation: Ö.E., E.P.; Literature Search: Ö.E., E.P.; Writing: Ö.E., E.P.; Critical Review: E.P., Ş.G.

Conflict of Interest: None declared.

Financial Disclosure: The authors declared that this study received no financial support.

\section{References}

1. Go MF. Natural history and epidemiology of Helicobacter pylori infection. Aliment Pharmacol Ther 2002;16:3-15. [CrossRef]

2. Yücel O, Sayan A, Yildiz M. The factors associated with asymptomatic carriage of Helicobacter pylori in children and their mothers living in three socio-economic settings. Jpn J Infect Dis 2009;62:120-4.

3. Malaty HM, Graham DY, Wattigney WA, Srinivasan SR, Osato M, Berenson GS. Natural history of Helicobacter pylori infection in childhood: 12-year follow-up cohort study in a biracial community and the Tulane center for. Clin Infect Dis 1999;28:27982. [CrossRef]

4. Cediel G, Pacheco-Acosta J, Castillo-Durán C. Vitamin D deficiency in pediatric clinical practice. Arch Argent Pediatr 2018;116:e75-81. [CrossRef]

5. Ahlawat R, Weinstein T, Pettei MJ. Vitamin D in pediatric gastrointestinal disease. Curr Opin Pediatr 2017;29:122-7. [CrossRef]

6. Franceschi F, Tortora A, di Rienzo T, D'Angelo G, laniro G, Scaldaferri $F$, et al. Role of Helicobacter pylori infection on nutrition and metabolism. World J Gastroenterol 2014;20:12809-17.

7. Jones NL, Koletzko S, Goodman K, Bontems P, Cadranel S, Casswall $\mathrm{T}$, et al. Joint ESPGHAN/NASPGHAN guidelines for the management of Helicobacter pylori in children and adolescents (update 2016). J Pediatr Gastroenterol Nutr 2017;64:991-1003. [CrossRef]

8. Grossman Z, Hadjipanayis A, Stiris T, del Torso S, Mercier JC, Valiulis $A$, et al. Vitamin $D$ in European children statement from the European Academy of Paediatrics (EAP). Eur J Pediatr 2017;176:829-31. [CrossRef]

9. Crabtree JE, Taylor JD, Heatley RV, Shallcross TM, Rathbone BJ, Wyatt Jl, et al. Mucosal IgA recognition of Helicobacter pylori
$120 \mathrm{kDa}$ protein, peptic ulceration, and gastric pathology. Lancet 1991;338:332-5. [CrossRef]

10. Polat E, Erolu E. Platelet indices: Impact of Helicobacter pylori infection. Cyprus J Med Sci 2020;5:136-8. [CrossRef]

11. Hooi JKY, Lai WY, Ng WK, Suen MM, Underwood FE, Tanyingoh D, et al. Global prevalence of Helicobacter pylori Infection: Systematic review and meta-analysis. Gastroenterology 2017;153:420-9. [CrossRef]

12. Ertem D. Clinical practice: Helicobacter pylori infection in childhood. Eur J Pediatr 2013;172:1427-34. [CrossRef]

13. Kienesberger S, Zechner EL. Helicobacter pylori Encyclopedia of Microbiology. Amsterdam, Netherlands: Elsevier Inc.; 2019.

14. Mommersteeg MC, Yu J, Peppelenbosch MP, Fuhler GM. Genetic host factors in Helicobacter pylori-induced carcinogenesis: Emerging new paradigms. Biochim Biophys Acta Rev Cancer 2018;1869:42-52. [CrossRef]

15. Chen LW, Chien CY, Hsieh CW, Chang LC, Huang MH, Huang $W Y$, et al. The associations between Helicobacter pylori infection, serum Vitamin $D$, and metabolic syndrome: A communitybased study. Medicine (United States) 2016;95:e3616. [CrossRef]

16. Öztürk N, Kurt N, Özgeriş FB, Baygutalp NK, Tosun MS, Bakan $\mathrm{N}$, et al. Serum zinc, copper, magnesium and selenium levels in children with Helicobacter Pylori Infection. Eurasian J Med 2015;47:126-9. [CrossRef]

17. Süoglu ÖD, Gökçe S, Saglam AT, Sökücü S, Saner G. Association of Helicobacter pylori infection with gastroduodenal disease, epidemiologic factors and iron-deficiency anemia in Turkish children undergoing endoscopy, and impact on growth. Pediatr Int 2007;49:858-63. [CrossRef]

18. Richter T, List S, Müller DM, Deutscher J, Uhlig HH, Krumbiegel $\mathrm{P}$, et al. Five- to 7-year-old children with Helicobacter pylori infection are smaller than Helicobacter-negative children: A cross-sectional population-based study of 3,315 children. J Pediatr Gastroenterol Nutr 2001;33:472-5. [CrossRef]

19. Gao T, Zhao M, Zhang C, Wang P, Zhou W, Tan S, et al. Association of Helicobacter pylori Infection with Vitamin D deficiency in infants and toddlers. Am JTrop Med Hyg 2020;102:541-6.

20. Janjetic MA, Mantero P, Rua EC, Balcarce N, De Palma GZ, Catalano $\mathrm{M}$, et al. Dietary and anthropometric indicators of nutritional status in relation to Helicobacter pylori infection in a paediatric population. Br J Nutr 2015;113:1113-9. [CrossRef]

21. Vestergaard $P$. Bone loss associated with gastrointestinal disease: Prevalence and pathogenesis. Eur J Gastroenterol Hepatol 2003;15:851-6. [CrossRef]

22. DeLuca HF. Overview of general physiologic features and functions of Vitamin D. Am J Clin Nutr 2004;80:1689-96. [CrossRef]

23. Türe $E$, Müderrisoğlu $S, A c ı$, Çubukçu M, Erdem MA. Evaluation of Vitamin $D$ levels in adolescents and children according to age, sex and seasonal characteristics. Ankara Med J 2020;20:380-6. [CrossRef]

24. Meral G, Guven A, Uslu A, Can G, Yozgatli AU, Yaprak P, et al. The prevalence of Vitamin $D$ deficiency in children, adolescents and adults in a sample of Turkish population. Stud Ethnomed 2016;10:249-54. [CrossRef] 